"Confirmatory analysis of the model to measure employee engagement"

\begin{tabular}{|c|c|c|}
\hline \multirow{2}{*}{ AUTHORS } & \multicolumn{2}{|c|}{$\begin{array}{l}\text { Lailah Imandin } \\
\text { Christo Bisschoff iD https://orcid.org/0000-0001-6845-7355 }\end{array}$} \\
\hline & \multicolumn{2}{|c|}{ Christoff Botha } \\
\hline ARTICLE INFO & \multicolumn{2}{|c|}{$\begin{array}{l}\text { Lailah Imandin, Christo Bisschoff and Christoff Botha (2016). Confirmatory } \\
\text { analysis of the model to measure employee engagement. Problems and } \\
\text { Perspectives in Management, 14(2), 93-103. doi: 10.21511/ppm.14(2).2016.10 }\end{array}$} \\
\hline DOI & \multicolumn{2}{|c|}{ http://dx.doi.org/10.21511/ppm.14(2).2016.10 } \\
\hline RELEASED ON & \multicolumn{2}{|l|}{ Wednesday, 11 May 2016} \\
\hline JOURNAL & \multicolumn{2}{|c|}{ "Problems and Perspectives in Management" } \\
\hline FOUNDER & \multicolumn{2}{|c|}{ LLC "Consulting Publishing Company "Business Perspectives" } \\
\hline & & 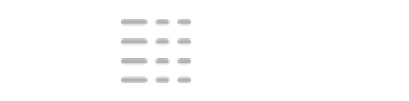 \\
\hline NUMBER OF REFERENCES & NUMBER OF FIGURES & NUMBER OF TABLES \\
\hline 0 & 0 & $\mathbf{0}$ \\
\hline
\end{tabular}

(C) The author(s) 2023. This publication is an open access article. 
Lailah Imandin (South Africa), Christo Bisschoff (South Africa), Christoff Botha (South Africa)

\title{
Confirmatory analysis of the model to measure employee engagement
}

\begin{abstract}
A model to measure the employee engagement was developed by researching historical employee engagement models. These models, consisting of employee engagement constructs and their measuring criteria, have been empirically validated and factorized into seven employee engagement factors. The seven employee engagement factors (of which factor one consists of two sub-factors) were subjected to confirmatory factor analysis to ensure the inclusion of the factors in the validated model to measure employee engagement. The model was also tested for goodness of fit, and the model shows good fit indices with the Comparative Fit Index (0.799), while the good model fit of the secondary fit indices RMSEA ( 0.078 within a narrow margin of 0.004$)$ and Hoelter $(113$ at $p<=0.1 ; 111$ at $p<=0.05)$ also show satisfactory model fit. Management can use the model as diagnostic tool to measure employee engagement and to apply it in managerial decisionmaking. On the other hand, academics could apply the model to extend their research in employee engagement.
\end{abstract}

Keywords: model fit, CFA, confirmed model, employee engagement.

JEL Classification: M50, M54.

\section{Introduction}

Employee engagement, according to Crabb (2011), has recently drawn a wealth of managerial attention, especially after research into the management concept indicated that a competitive advantage could be achieved by organizations with engaged employees (Towers Perrin, 2007). However, it seems that this attention results mainly from practitioners, and that scientific research by academia are lacking, especially with regard to measuring and determining what the current level of employee engagement is in an organization (Saks, 2006 in Kular et al., 2008).

A modern definition of employee engagement, according to Reilly $(2014$, p. 1$)$ is that:

"Engaged workers stand apart from their not-engaged and actively disengaged counterparts because of the discretionary effort they consistently bring to their roles. These employees willingly go the extra mile, work with passion, and feel a profound connection to their company. They are the people who will drive innovation and move your business forward".

The additional productivity of engaged employees is appealing to managers in addition to other benefits such as employees taking less sick leave, lower rates of resignation and stability in the workforce (CIPD Annual Survey Report, 2014). Resultantly, management of organizations realized that if they could have a significant effect on their employees' levels of engagement, they could improve performance of the organization. To do so, managers required a scientific and reliable method to actually measure employee engagement, and

(C) Lailah Imandin, Christo Bisschoff, Christoff Botha, 2016.

Lailah Imandin, Ph.D., NWU Potchefstroom Business School, North-

West University, South Africa \& The Management College of South Africa, South Africa.

Christo Bisschoff, Ph.D., Professor, NWU Potchefstroom Business School, North-West University, South Africa.

Christoff Botha, Ph.D., Professor, NWU Potchefstroom Business

School, North-West University, South Africa. thereby empower themselves to introduce managerial interventions to engage employees.

\section{Problem statement}

Although employee engagement generates substantial interest among managers and academia, Imandin, Bisschoff and Botha (2015a) identified that a notable gap exists on how to actually measure employee engagement in the workplace. Despite the popularity and recognized influence in productivity, research in employee engagement, thus, far has revealed that there are existing models that support the importance of employee engagement, but that there is a shortage of research aimed at developing a model to measure employee engagement. The research surrounding employee engagement up to now proves informative. But it has focused mainly on how organizations engage their employees. Typical examples of employee engagement models are:

- The Corporate Leadership Council's model of engagement as presented by the Corporate Executive Board (2010, p. 5) defines engagement as the extent to which employees commit to something or someone in their organization, how hard they work, and how long they stay as a result of that commitment. This view represents an outcome-focused model of engagement.

- Shuck et al. (2011, p. 429) developed a conceptual model of employee engagement. This model employs three variables, namely, job fit, affective commitment, and psychological climate as influences in the development of employee engagement. The variables identified are limited and do not cover a range of influencing variables of employee engagement.

Developing a model to measure employee engagement required a series of steps, namely, to identify employee engagement drivers and their respective measuring criteria to statistically purify and validate the model, and to actually measure 
employee engagement. However, despite the fact that the model is statistically validated (Imandin, Bisschoff \& Botha, 2015b, p. 87), the model and its individual factors with their measuring criteria also need to be confirmed as statistically significant to employ in measuring employee engagement. In addition, the model also needs to be assessed for model fit, and, as such, indicate the goodness of the model as a measuring tool for employee engagement. This is, at present, outstanding in the model to measure employee engagement, and, consequently, the model cannot be employed with confidence in the measurement of employee engagement.

\section{Objectives}

The primary objective was to confirm the model to be a valid model measure of employee engagement. This objective was achieved by the following secondary objectives:

1. confirm the employee engagement factors and their measuring criteria as factors to measure employee engagement;

2. assess the importance of each of these factors in the measuring of the employee engagement model;

3. determine the significance $(p<=0.05)$ of the factors measuring employee engagement;

4. ensure importance and significance $(p<=0.05$ ) of the measuring criteria pertaining to each of the factors; and

5. determine the model fit by means of recognized fit indices.

\section{The model to measure employee engagement}

Based on the theoretical study, a total of 11 employee engagement constructs have been identified from the literature study. These constructs are discussed in Table 1 (see Appendix).

The theoretical model and its 11 constructs to measure employee engagement were submitted to exploratory factor analysis, aiming to simplify the model, while weeding out the unimportant criteria and constructs (Imandin, Bisschoff and Botha, 2015a, p. 57). The original 11 constructs were reduced to seven, while construct one consists of two sub-constructs. The constructs are:

1. employee perceptions on management and leadership (which consists of two sub-factors):

a. employees' perceptions of management; and

b. engaged leadership team;

2. behavioral engagement;

3. change management and stress-free environment;

4. career growth opportunities;

5. emotional engagement;

6. nature of my job; and

7. feeling valued and involved.
These retained constructs have been validated statistically and employed to measure employee engagement among managers (Imandin et al., 2015a, 2015b). The managers deemed all the factors to be important, signifying that behavioral engagement is the most important construct according to the respondents, while they rate career growth opportunities to be the lowest factor of importance. The initial model shows good fit at $69.75 \%$ of variance explained, while the constructs all show significant inter-correlations. Despite these positive findings by Imandin (2015a, 2015b), the final analysis needs to be done, namely, to determine the goodness of fit of the model to measure employee engagement. Once the constructs and their relative importance have been confirmed and statistically calculated, a final verdict on the model can be rendered regarding its model fit and, subsequently, its suitability to be employed as managerial tool to measure employee engagement.

\section{Research methodology}

The research methodology consists of both a literature study and an empirical study.

\section{Literature study}

The literature study focuses on employee engagement, covering, firstly, the drivers of employee engagement, secondly, the measuring criteria of employee engagement, and, thirdly, validity and reliability theory in model construction. The literature forms a solid theoretical basis for the study. The literature study employed accredited journal articles, textbooks, model development theory from similar studies (in different disciplines), conference proceedings and internet databases and internet searches. The university libraries of the North-West University and Mancosa Graduate School of Business were used to source relevant information with the aid of a specialized postgraduate research librarian.

5.1. Empirical study. 5.1.1. Research instrument. The structured questionnaire to measure employee engagement was specifically developed from the theory of the study. To do so, a number of employee engagement models were identified. The employee engagement drivers were identified from the models and further researched. The questionnaire employed 11 employee engagement drivers, which were measured by 94 measuring criteria. In addition, the questionnaire measured demographic variables of the managers. It recorded data on a five-point Likert scale that ranged from: $1=$ strongly agree to $5=$ strongly disagree.

5.1.2. Sampling and data collection. A stratified sample was drawn by selecting the study schools of advanced management training programs of a selected 
business school. The managers attending these study schools are diverse in culture, geography, gender and nationality, thereby providing access to a diverse sample. The questionnaire was administered to managers attending the study schools of the Management College of South Africa's Master in Business Administration degree in Durban and Johannesburg. This sample was purposefully selected after guidance by Moolla (2010), who employed a similar sample in developing a brand loyalty model. The advantages of this sample are that:

- the sample consisted of middle and top managers with a minimum of three years' work experience;

- it sets a minimum educational level for entry into the research;

- it represents a segment that is more informed about contemporary business practices;

- it represents a community that is more likely to analyze their own careers and employee engagement perceptions;

- it represents middle to higher income earners who have a wider economic freedom and alternative employment exposure;

- it represents a segment of middle to higher income earners who are less susceptible to economic turbulence;

- it represents a segment that falls between the LSM 6 and LSM 10 categories;

- they would be able to understand the terminology and nomenclature used in the questionnaire; and

- they are more educated in terms of higher order employment issues such as engagement and managerial interventions.

This sample also had the embedded advantage that data collection was quick and the environment controllable, and, consequently, a good response rate was expected. The questionnaires were distributed in the class situation and respondents were given ample time to complete the questionnaires. The questionnaires were anonymous and confidentiality was guaranteed. Completion was voluntarily and the questionnaire also enjoyed the ethical clearance of the North-West University's faculty ethical committee. A total of 300 questionnaires were distributed and a total of 260 usable questionnaires were received back. Some 22 respondents opted out, while the other 18 only partially completed the questionnaires. These questionnaires were discarded from the analysis. This signified a satisfactory response rate of $86.6 \%$.

5.1.3. Statistical analysis. The Statistical Package for Social Sciences software (SPSS, Version 22.0 for Windows, as well as the add-on package AMOS performing structural equation and confirmatory factor analysis) was used as the software for the quantitative analysis. As suggested by Hamid (2014, pp. 7-8), the befitting level of quantitative statistical techniques appropriate to a doctoral study was employed to analyze the data.

5.1.4. Model fit indices employed. The model is tested and confirmed by the confirmatory factor analysis, indicating the relative importance and significance of the factors, while the goodness of model fit was also determined (Rahn, 2015). The classic goodness of fit index is the $\chi^{2}$ - chi square. The chi-square test, according to Field (2007), indicates the amount of difference between expected and observed covariance matrices. A chi-square value close to zero indicates little difference between the expected and observed covariances (Suhr, 2006). In addition, the probability level must be greater than 0.05 when the chi-square is close to zero. Brown and Moore (2013) state that, while chi-square is routinely reported in CFA research, other fit indices are usually relied on more heavily in the evaluation of model fit. These include the standardized root mean square residual (SRMR), root mean square error of approximation (RMSEA), Tucker-Lewis index (TLI) and the comparative fit index (CFI). It is suggested that each of these fit indices be reported and considered, because they provide different information about the model fit. In addition, Arbuckle (2012) and Moolla and Bisschoff (2013) add the Hoelter index as an additional measure for model fit. This study employed three indices of model fit, namely, the CFI, RMSEA and Hoelter to establish the goodness of model fit.

\section{Results}

6.1. Goodness of model fit. Measuring or determining the goodness of a model fit is performed by a number of model fit indices. In this regard, model fit is defined by Kenny (2014) as the "ability of a model to reproduce the data (that is, usually the variancecovariance matrix)". Kenny also points out that it should also be noted that a good-fitting model is not necessarily a valid model, and vice versa.

Fit indices consist of both normed and non-normed fit indexes. Both are used to determine the goodness of fit of a model. However, Moolla and Bisschoff (2013, pp. 7-8) point out that: "one disadvantage of typical indices is that they are influenced by the population parameters of the research". To address this deficiency, Bentler and Bonnet (in Moolla, 2010) proposed that two coefficients should be used to address the deficiency of population parameters, namely, the comparative fit index (CFI) for normed and the non-normed fit index (FI) to determine the fit of the model. Bentler (1990, p. 240) continues and 
points out that the CFI avoids the underestimation of fit often noted in small samples, but it also performs well at all sample sizes. However, Zen (2007) renders a verdict on the debate of baseline fit indices by indicating that the CFI is a suitable index to employ as routine fit measure.

In the interpretation of the CFI, a value above 0.9 is regarded to be a very good fit (Konovsky and Pugh, 1994, p. 662). Regarding exploratory research, Du Plessis (2010) and Moolla and Bisschoff (2013, p. 9), however, point out that a CFI index of 0.80 is satisfactory, and that even a CFI of 0.75 could indicate a fair fitting model.

The model to measure employee engagement returned a comparative fit index (CFI) of 0.799 (see Table 2). This index signifies a fair fit as it is marginally below the 0.80 as index value.

Table 2. Comparative fit index (CFI)

\begin{tabular}{|l|c|c|c|c|c|}
\hline \multicolumn{1}{|c|}{ Model } & $\begin{array}{c}\text { NFI } \\
\text { Delta1 }\end{array}$ & $\begin{array}{c}\text { RFI } \\
\text { rho1 }\end{array}$ & $\begin{array}{c}\text { IFI } \\
\text { Delta2 }\end{array}$ & $\begin{array}{c}\text { TLI } \\
\text { rh02 }\end{array}$ & CFI \\
\hline Default model & .719 & .701 & .800 & .785 & .799 \\
\hline Saturated model & 1.000 & & 1.000 & & 1.000 \\
\hline Independence model & .000 & .000 & .000 & .000 & .000 \\
\hline
\end{tabular}

The root mean square error of approximation (RMSEA) is a popular and widely applied model fit index (Zen, 2007). Ideally, the RMSEA should be lower than 0.05 and models with a RMSEA of 0.10 or more have poor fit (Dixon and Dixon, 2010, p. 117). The results pertaining to RMSEA are depicted in Table 3.

Table 3. Root mean square error of approximation

\begin{tabular}{|l|c|c|c|c|}
\hline \multicolumn{1}{|c|}{ Model } & RMSEA & LO 90 & HI 90 & PCLOSE \\
\hline Default model & .078 & .076 & .080 & .000 \\
\hline Independence model & .169 & .167 & .171 & .000 \\
\hline
\end{tabular}

The model possesses a moderate fit with RMSEA between 0.05 and 0.1 . It has a lower confidence limit of 0.076 and a higher limit of 0.080 . These limits indicate a very narrow confidence interval (0.004). Together with the RMSEA value and narrow confidence interval, the model can be considered a good fit of the model to the population (Moolla and Bisschoff 2013, p. 5; Browne and Cudeck, 1997, pp. 232-243). Regarding the $p$ of close fit (PCLOSE) test, where the $p$-value examines the alternative hypothesis when the RMSEA is greater than 0.05 , the model returns a $p$-value of 0.00 . A $p$-value that is greater than 0.05 signifies that the fit of the model is a close fit (Garson, 2010, in support of Newsom, 2005). However, with regard to the $p$-value, the employee engagement model's $p$-value does not confirm a good fit, according to the PCIOSE value of the RMSEA fit index. Zen (2007), more importantly, observes that a RMSEA value equal to or less than 0.80 represents an "adequate model fit". Therefore, for this model, with an RMSEA of 0.78 marginally below 0.80 , it is concluded that an adequate model fit exists.

The goodness-of-fit for the model, according to the Hoelter index, is used to judge the critical sample size $(\mathrm{N})$; therefore, whether the sample size is adequate. A Hoelter's $\mathrm{N}$ under 75 is considered unacceptably low to accept a model by chi-square (Newsom, 2005).

Table 4. Hoelter's index (N)

\begin{tabular}{|l|c|c|}
\hline \multicolumn{1}{|c|}{ Model } & HOELTER .05 & HOELTER .01 \\
\hline Default model & 111 & 113 \\
\hline Independence model & 33 & 34 \\
\hline
\end{tabular}

The Hoelter's N returns two values at the following levels of significance: 0.05 and 0.01 (Arbuckle, 2012). The model to measure employee engagement returns an acceptable value of 113 at the 0.01 and 111 at the 0.05 levels of significance, respectively. Hoelter's index signifies a very good model fit.

In summary, the model fit is satisfactory. Although the CFI as primary fit index is marginally below 0.80 , a CFI of 0.90 or higher would have provided a better fit, but, in defence of the model, it is an exploratory model and the fit is not expected to be in that category of fit, nor is it deemed imperative, because the model is exploratory in nature and not a final and operationalized model (Bisschoff and Moolla, 2014). Furthermore, considering RMSEA signifying an adequate model fit (Zen, 2007) (or fair model fit according to Browne and Cudeck, 1997, pp. 232-243), and Hoelter's index which signifies a good model fit, the model to measure employee engagement is regarded to be a satisfactory model.

\section{Importance of the constructs}

The importance of the constructs measuring employee engagement is determined by the regression weights of the constructs (Statistical Solutions, 2013). The summarized model and its regression weights per factor and sub-factors appear in Figure 1 (Table 5 in Appendix contains the detailed regression weights of all the measuring criteria pertaining to the employee engagement factors and their measuring criteria). 


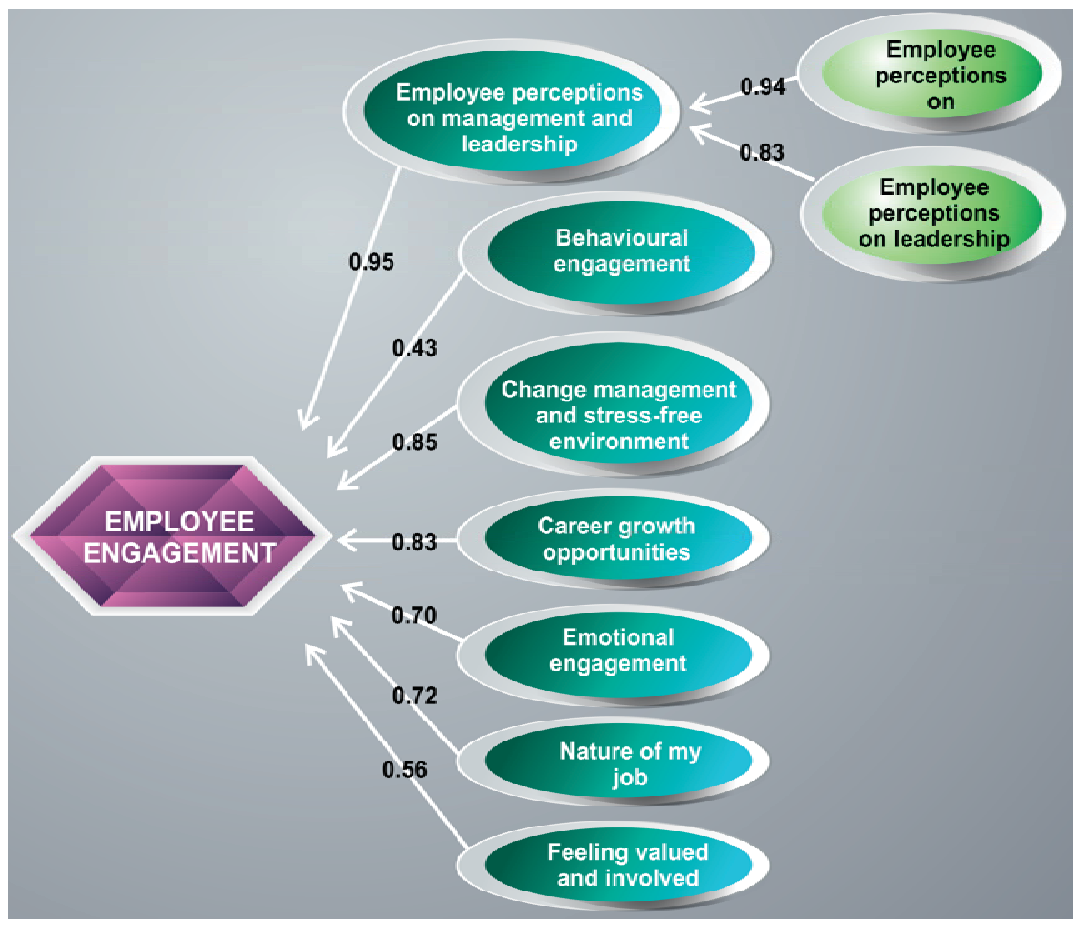

Fig. 1. Model to measure employee engagement

Significance: $p<=0.05$.

From the Figure, it is clear that the factor employee perceptions on management and leadership is regarded as the most important contributing construct $(0.95)$ in the model with a regression weight of 0.95 (strongly supported by the two sub-constructs employee's perceptions of management (0.94) and engaged leadership team (0.83)). This is followed by change management and stress-free environment (0.85), career growth opportunities (0.83), nature of my job (0.72), emotional engagement (0.70), feeling valued and involved (0.56) and, then, behavioral engagement (0.43). Despite the regression weights and their indicative power of importance, it is important to note that all seven constructs are significant and, as such, valued in measuring the employee engagement of managers.

\section{Conclusions}

From the results, it can be concluded that:

- all seven factors are important in their contribution (according to the regression weights) to the model to measure employee engagement;

- the measuring criteria pertaining to the factors are both important (regression weights) and significant $(p<=0.05)$ with regard to their contribution to the respective factors;
- the factors in the model are significant at $p<=0.05$;

- management and leadership are playing a major role in employee engagement, and both play important roles in the first factor;

- the model possesses a satisfactory fit (pertaining to exploratory research); and

- the model is a suitable and applicable to measure employee engagement.

\section{Summary}

The model to measure employee engagement was developed from an in-depth literature review that originally identified 12 engagement constructs and their measuring criteria. These constructs and their measuring criteria were empirically validated, and the data were tested for reliability. The model was developed and empirically evaluated using a variety of statistical techniques, resulting in seven constructs with one construct consisting of two sub-constructs. The constructs were subjected to confirmatory factor analysis to ensure that they are relevant and, also, to determine their relative importance to the model. In addition, the model fit was determined using the CFI, Hoelter's and the RMSEA indices. The model displays a satisfactory fit, signifying that it can be employed as measuring tool by management and researchers to measure employee engagement.

\section{References}

1. Arbuckle, J.L. (2012). Users Guide. IBM® SPSS® Amos ${ }^{\mathrm{TM}}$ 21. Available at: ftp://public.dhe.ibm.com/ software/analytics/spss/documentation/amos/21.0/en/Manuals/IBM_SPSS_Amos_Users_Guide.pdf.

2. Aveta Business Institute. (2014). Six Sigma certification. Available at: www.sixsigmaonline.org. 
3. Bentler, P.M. (1990). Comparative fit indexes in structural models, Psychology Bulletin, 107 (4), pp. $238-246$.

4. Bisschoff, C.A. and Moolla, A.I. (2014). A simplified model to measure brand loyalty. Proceedings of the $2^{\text {nd }}$ International Conference on Contemporary Marketing Issues (ICCMI), Athens, Greece. June 18-20, pp. 1113-1119.

5. Brown, T.A. and Moore, M.T. (2013). Confirmatory factor analysis. Available at: www.researchgate.net.

6. Browne, M.W. and Cudeck, R. (1997). Alternative ways of assessing model fit, Social Methods and Research, 21 (2), pp. 230-258.

7. Brunone, C. (2013). Leadership development vs. Employee engagement. Available at: http://www.blessingwhite.com/content/articles/enews/June2013.asp?pid=2.

8. Chartered Institute of Personnel Development. (2014). Employee engagement. Available at: http://www.cipd.co.uk/hr-resources/factsheets/employee-engagement.aspx

9. Collins, M. (2014). Recruitment \& HR Services Group. Available at: www.collinsmnicholas.ie/blog/?p==660. Accessed: 10 May 2013.

10. Corporate Executive Board. (2010). Corporate Executive Board Research report. Available at: http://www.executiveboard.com/.

11. Crabb, S. (2011). The use of coaching principles to foster employee engagement, The Coaching Psychologist, 7 (1), pp. 27-34.

12. Crim, D. and Seijts, G. (2006). What engages employees the most or, the ten Cs of employee engagement, Ivey Business Journal. Available at: http://iveybusinessjournal.com/ topics/the-workplace/what-engages-employeesthe-most-or-the-ten-cs-of-employee-engagement.

13. Custominsight. (2013). A 360 degree insight: Employee engagement. Available at: http://custominsight.com.

14. Dicke, C., Holwerda, J. and Kontakos, A.M. (2007). Employee engagement. What do we really know? What do we need to know to take action? Paris: CAHRS.

15. Dixon, J. and Dixon, M. (2010). Confirmatory factor analysis. Amsterdam: Springer.

16. Du Plessis, J. (2010). Statistical Consultation Services. Potchefstroom: North-West University.

17. Field, A. (2007). Understanding statistics using SPSS. London: Sage.

18. Gallup. (2011). Employee engagement: What's your employee ratio? Washington, DC: Gallup.

19. Gallup. (2012). Employee engagement and performance. Available at: http://www.gallup.com/ consulting/52/employee-engagement.aspx.

20. Garson, G.D. (2010). Structural equation modelling. Available at: http://www.psych.cornell.edu/darlington/ factor.htm

21. Hamid, Z. (2014). Stress management and its impact on the work performance of educators in Swaziland. Potchefstroom: North-West University. (Thesis - Ph.D.).

22. Hewitt, A.O.N. (2011). The multiplier effect: Insights into how senior leaders drive employee engagement higher. Available at: http://www.aon.com/attachments/thought-leadership/Aon-Hewitt-White-paper_Engagement.pdf.

23. Holtsman, S. and Vezzu, S. (2011). Confirmatory factor analysis and structural equation modeling of noncognitive assessments using PROC CALIS. Available at: http://www.nesug.org/proceedings/nesug11/sa/sa07.pdf.

24. Hughes, J.C. and Rog, E. (2008). Talent management: A strategy for improving employee recruitment, retention and engagement within hospitality organizations, International Journal of Contemporary Hospitality Management, 20 (7), pp. 743-757.

25. Imandin, I., Bisschoff, C.A. and Botha, C.J. (2015a). Validating a model to measure employee engagement, Kasmera, 43 (8), pp. 57-91.

26. Imandin, I., Bisschoff, C.A. and Botha, C.J. (2015b). Measuring employee engagement of South African Managers, Journal of Psychology, 13 (2), pp. 129-142.

27. Johnson, M. (2011). Workforce Deviance and the Business Case for Employee Engagement, Journal for Quality \& Participation, 34 (2), pp. 11-16.

28. Kahn, W.A. (2009). Psychological conditions of personal engagement and disengagement at work, Academy of Management Journal, 33 (4), pp. 692-724.

29. Kanaka, M.L.G. (2012). Employee Engagement: A corporate boon, 10 ways for effective engagement, Advances in Management, 5 (2), pp. 64-65.

30. Kenny, D. (2014). Measuring model fit. Available at: http://davidakenny.net/cm/fit.

31. Konovsky, M.A. and Pugh, S.D. (1994). Citizen behavior and social change, Academy of Management Journal, 37 (3), pp. 656-69.

32. Konrad, A.M. (2006). Engaging employees through high-involvement work practices, Ivey Business Journal. Available at: http://iveybusinessjournal.com/topics/the-workplace/engaging-employees-through-highinvolvement-work-practices.

33. Kular, S., Gatenby, M., Rees, C., Soane, E. and Truss, K. (2008). Employee engagement: a literature review. Available at: http://eprints.kingston.ac.uk/4192/1/19wempen.pdf.

34. London, M. and Mone, E.M. (2009). Strategic performance management: Issues and trends. London: Routledge.

35. Mone, E., Eisinger, C., Guggenheim, K., Price, B. and Stine, C. (2011). Performance management at the wheel: Driving employee engagement in organizations, Journal of Business and Psychology, 26 (2), pp. 205-212.

36. Moolla, A.I. (2010). A conceptual framework to measure brand loyalty. Potchefstroom: North-West University.

37. Moolla, A.I. and Bisschoff, C.A. (2013). An empirical model that measures brand loyalty of fast-moving consumer goods, Journal of Economics, 4 (1), pp. 1-9. 
38. Newsom, M. (2005). Some clarifications and recommendations on fit indices. Available at: https://www.google.co.za/\#q=ecvi+CFA+model+fit+interpretation.

39. Parkes, L. (2011). Employee engagement. Igniting Passion through purpose, participation and progress. In California State University. Available at: http://www.fullerton.edu/cice/ Documents/2013CEReport.pdf.

40. Rahn, M. (2015). Factor analysis: The difference between confirmatory and exploratory factor analysis. Available at: http://www.theanalysisfactor.com/confirmatory-and-exploratory-factor-analysis/.

41. Reilly, R. (2014). Five ways to improve employee engagement now. Available at: http://www.gallup.com/businessjournal/166667/five-ways-improve-employee-engagement.aspx.

42. Robinson, D., Perryman, S. and Hayday, S. (2004). The drivers of employee engagement. London: Institute for employment studies.

43. Shroeder-Saulnier, D. (2010). Employee engagement: Drive organizational effectiveness by building trust. Right management: A manpower company. Available at: http://www.right.com/ thought-leadership/e-newsletter/driveorganizational-effectiveness-by-building-trust.pdf.

44. Shuck, B. and Reio, T. (2013). Employee engagement and wellbeing: A moderation model and implications for practice, Journal of Leadership and Organizational Studies, 11 (2), pp. 156-181.

45. Shuck, B., Reio, G. and Rocco, S. (2011). Employee engagement: an examination of antecedent and outcome variables, Human Resource Development International, 14 (4), pp. 427-445.

46. Statistical Package for Social Sciences. (2014). SPSS Version 22 AMOS add-on included. Available at: http://www-01.ibm.com/software/za/analytics/spss/.

47. Statistical Solutions. (2013). Confirmatory factor analysis. Available at: http://www.statisticssolutions.com/academicsolutions/resources/directory-of-statistical-analyses/confirmatory-factor-analysis.

48. Suhr, D.D. (2006). Exploratory or confirmatory factor analysis? Available at: http://www2.sas.com/proceedings/sugi31/toc.html.

49. Treasury Board of Canada Secretariat. (2011). Public service employee survey: Focus on employee engagement. Available at: http://www.tbs-sct.gc.ca/pses-saff/2011/engage-mobil-eng.asp.

50. Towers Perrin. (2007). Closing the engagement gap: A road map for driving superior business performance. Available at: http://www.biworldwide.com/info/pdf/.

51. Vance, R.J. (2006). Employee Engagement and Commitment. New York, NY: The SHRM Foundation. Available at: http://www.vancerenz.com/researchimplementation/uploads/1006employee engagementonlinereport.pdf.

52. Zen, C. (2007). Assess whole SEM model chi square and fit index. Available at: http://zencaroline.blogspot.com/2007/04/global-model-fit.html.

\section{Appendix}

Table 1. Employee engagement constructs

\begin{tabular}{|c|c|c|c|}
\hline № & Construct & Description & Researchers \\
\hline 1 & Cognitive drivers & $\begin{array}{l}\text { The levels of cognitive engagement originate from employees' appraisal of whether } \\
\text { their work is meaningful, safe (physically, emotionally, and psychologically), and if they } \\
\text { have sufficient levels of resources to complete their work. This psychological } \\
\text { interpretation of work reflects: } \\
\text { a level of engagement in or movement toward their work; } \\
\text { paralleling the broadening of resources; and that } \\
\text { those who believe their work matters embrace and engage it. } \\
\text { Employees who experience negative work circumstances (such as a negative } \\
\text { workplace climate or organizational culture) develop a downward spiral of emotions } \\
\text { that often ends in feelings of loneliness, ostracism and burnout. Such negative work } \\
\text { environment makes workers feel irritable, anxious and defensive, potentially leading to } \\
\text { poor productivity, a lack of motivation and morale, and poor communication. } \\
\text { A positive workplace environment is filled with employees who believe they have a } \\
\text { purpose at their jobs, they are making a difference, adding to the growth of the } \\
\text { company or simply being a valuable part of the team. A negative environment lacks } \\
\text { this feeling - the employees will feel they are performing work that does not serve a } \\
\text { purpose. Without a sense of purpose, the motivation to complete responsibilities with } \\
\text { pride and enthusiasm is hard to come by. Cognitive engagement revolves around how } \\
\text { employees appraise their workplace climate, as well as the tasks they are involved in. } \\
\text { As an employee makes an appraisal, they determine levels of positive or negative } \\
\text { affect, which, in turn, influences behavior. Cognitively engaged employees are } \\
\text { positively work-orientated and exhibit higher levels of productivity. }\end{array}$ & $\begin{array}{l}\text { Shuck \& Reio (2013), Mone et al. } \\
\text { (2011), London \& Mone (2009), } \\
\text { Gallup (2011), Brown \& Leigh } \\
\text { (1996 in Shuck \& Reio, 2013), } \\
\text { Fredrickson (1998, 2001 as cited } \\
\text { by Shuck \& Reio, 2013), Kahn } \\
\text { (2009), Collins (2014), TBS (2011) }\end{array}$ \\
\hline 2 & Emotional engagement & $\begin{array}{l}\text { Emotional engagement revolves around the broadening and investment of the emotional } \\
\text { resources employees have within their influence. When employees are emotionally } \\
\text { engaged with their work, they invest personal resources such as pride, trust, and } \\
\text { knowledge. The investment of such resources may seem trivial at first glance; however, } \\
\text { consider the work of prideful employees who fully trust their work environment. Managing } \\
\text { employee emotions relates to intrapersonal intelligence: the ability to be self-aware, } \\
\text { acknowledge and understanding one's own thoughts, feelings and emotions. An } \\
\text { individual must be able to fully focus on the tasks that they are undertaking, rather than } \\
\text { be distracted by negative or irrelevant thoughts, if they are to develop the right mindset for } \\
\text { engagement. Accordingly, these feelings of positive emotion broaden an employee's } \\
\text { available resources and enhance critical and creative thinking processes. During the }\end{array}$ & $\begin{array}{l}\text { Shuck \& Reio (2013), Hughes \& } \\
\text { Rog (2008), Gallup (2011) }\end{array}$ \\
\hline
\end{tabular}


Table 1 (cont.). Employee engagement constructs

\begin{tabular}{|c|c|c|c|}
\hline № & Construct & Description & Researchers \\
\hline 2 & Emotional engagement & $\begin{array}{l}\text { emotional engagement process, feelings and beliefs an employee holds influence and } \\
\text { direct outward energies toward task completion. Emotional drivers such as one's } \\
\text { relationship with one's manager and pride in one's work have a greater impact on } \\
\text { discretionary work effort than do the rational drivers, such as salary and benefits. }\end{array}$ & $\begin{array}{l}\text { Shuck \& Reio (2013), Hughes \& } \\
\text { Rog (2008), Gallup (2011) }\end{array}$ \\
\hline 3 & Behavioral engagement & $\begin{array}{l}\text { Behavioral engagement is the most overt form of the employee engagement process. } \\
\text { It is often described as "what we can see someone does". Understood as the physical } \\
\text { manifestation of the cognitive and emotional engagement combination, behavioral } \\
\text { engagement can be understood as increased levels of effort directed toward } \\
\text { organizational goals. Resultantly, behavioral engagement can be described as the } \\
\text { broadening of an employee's available resources displayed overtly. } \\
\text { A managerial challenge is that engagement is derived based on how employees feel } \\
\text { about their work experiences. Fundamentally, engagement is about whether an } \\
\text { employee desires to put forth discretionary effort. Engaged employees exhibit the } \\
\text { following clear behaviors: } \\
\text { Belief in the organization refers to 'sharing the DNA', where employees } \\
\text { demonstrate an extremely strong belief in the purpose, values and work of the } \\
\text { organization. } \\
\text { Desire to improve their work: engaged employees are willing to put forth } \\
\text { discretionary effort into their work in the form of time, brainpower and energy, } \\
\text { above and beyond what is considered adequate. } \\
\text { An understanding of the business strategy: an organization is aligned when all } \\
\text { have a commonality of purpose, a shared vision, and an understanding of how } \\
\text { their personal roles support the overall strategy. } \\
\text { The ability to collaborate with and assist colleagues. } \\
\text { The willingness to demonstrate extra effort in their work (defined as an } \\
\text { employee's willingness to engage in discretionary effort and an employee's } \\
\text { willingness to go above minimal job responsibilities). } \\
\text { The drive to continually enhance their skills set and knowledge base. Employees } \\
\text { who enhance their skills through training are more likely to engage fully in their } \\
\text { work, because they derive a satisfaction from mastering new tasks. } \\
\text { Consequently, it is concluded that engaged employees are those who are willing to put } \\
\text { forth discretionary effort in order to ensure the organization is successful. }\end{array}$ & $\begin{array}{l}\text { Shuck \& Reio (2013, p. 161), } \\
\text { Johnson (2011), Shuck et al. } \\
\text { (2011), Parkes (2011), Vance } \\
\text { (2006), Shroeder-Saulnier (2010) }\end{array}$ \\
\hline 4 & $\begin{array}{l}\text { Feeling valued and } \\
\text { involved }\end{array}$ & $\begin{array}{l}\text { High-involvement work practices can develop the positive beliefs and attitudes } \\
\text { associated with employee engagement, and these practices can generate the kinds of } \\
\text { discretionary behaviors that lead to enhanced performance. High-involvement work } \\
\text { practices that provide employees with the power to make workplace decisions, training } \\
\text { to build their knowledge and skills in order to make and implement decisions } \\
\text { effectively, information about how their actions affect business unit performance, and } \\
\text { rewards for their efforts to improve performance, can result in a win-win situation for } \\
\text { employees and managers. Research has indicated that the driver 'feeling valued and } \\
\text { involved is one of the strongest drivers and organizations need to understand the } \\
\text { voice of the employee and be aware of employees' needs, issues and values. Aspects } \\
\text { such as involvement in decision-making, ability to voice ideas and managers listening } \\
\text { to these views and value employees' contributions, opportunities employees have to } \\
\text { develop their jobs, and the extent to which the organization demonstrates care for its } \\
\text { employees' health and well-being have been identified as key components that } \\
\text { contribute to feeling valued and involved. }\end{array}$ & $\begin{array}{l}\text { Johnson (2011), Shuck et al. } \\
\text { (2011), Gallup (2011), Konrad } \\
\text { (2006), Robinson et al., 2004) }\end{array}$ \\
\hline 5 & $\begin{array}{l}\text { Having an engaged } \\
\text { leadership team }\end{array}$ & $\begin{array}{l}\text { Effective leadership is engagement. Having leaders who can help cascade the vision } \\
\text { and inspire others to exceptional performance is an equally important part of making } \\
\text { engagement flourish in your team, your department and your company. An analysis of } \\
\text { companies with strong financial results shows that one distinguishing feature is the } \\
\text { quality of their senior management. In particular, senior managers' levels of } \\
\text { engagement are high and their ability to engage others in the organization, particularly } \\
\text { those in middle management, is strong. Engaged managers are more likely to build } \\
\text { engaged teams. In essence, engagement starts at the top, and without engaged } \\
\text { senior leadership, companies will not be able to engage the hearts and minds of their } \\
\text { employees. This means that leaders: } \\
\text { 1. Come across as more connected with employees meaning that they: } \\
\text { effectively communicate the organization's goals and objectives; } \\
\text { consistently demonstrate the organization's values in all behaviors and actions; } \\
\text { appropriately balance employee interests with those of the organization; and } \\
\text { fill employees with excitement for the future of the organization. } \\
\text { Are performance focused, which entails: } \\
\text { effectively communicate the organization's goals and objectives; } \\
\text { empower managers and employees and instil a culture of accountability; and } \\
\text { set aggressive goals at all levels of the organization. } \\
\text { Are future and development oriented and focus to: } \\
\text { communicate the importance of spending time on feedback and provide } \\
\text { performance coaching; } \\
\text { fill employees with excitement about the future of the organization; } \\
\text { effectively communicate the skills/capabilities employees must develop for future } \\
\text { success; and } \\
\text { invest in long-term growth opportunities, even during difficult times. }\end{array}$ & $\begin{array}{l}\text { Johnson (2011), London \& Mone } \\
\text { (2009), Mone et al. (2011), Kanaka } \\
\text { (2012), Gallup (2011), Brunone } \\
\text { (2013), Hewitt (2013), Crim \& } \\
\text { Seijts (2006), Mone et al. (2011) }\end{array}$ \\
\hline
\end{tabular}


Table 1 (cont.). Employee engagement constructs

\begin{tabular}{|c|c|c|c|}
\hline № & Construct & Description & Researchers \\
\hline 5 & $\begin{array}{l}\text { Having an engaged } \\
\text { leadership team }\end{array}$ & $\begin{array}{l}\text { Managers drive engagement when they provide ongoing feedback and recognition to direct } \\
\text { and improve performance and have career-planning discussions with their employees. }\end{array}$ & $\begin{array}{l}\text { Johnson (2011), London \& Mone } \\
\text { (2009), Mone et al. (2011), Kanaka } \\
\text { (2012), Gallup (2011), Brunone } \\
\text { (2013), Hewitt (2013), Crim \& Seijts } \\
\text { (2006), Mone et al. (2011) }\end{array}$ \\
\hline 6 & Trust and integrity & $\begin{array}{l}\text { The first job of any leader is to inspire trust. Trust is confidence born of two dimensions: } \\
\text { character and competence. Character includes one's integrity, motive and intent with people. } \\
\text { Trust and integrity are defined as the extent to which the organization's leadership is } \\
\text { perceived to care about employees, listens and responds to their opinions, is trustworthy, } \\
\text { and 'walks the talk'. Having a manager employees can trust is a primary driver of } \\
\text { engagement. Building trust through effective communications is an absolute essential. } \\
\text { Employees need to trust that their leaders have the capability to make the organization } \\
\text { successful. To win that trust, leaders must show that they have a plan, articulate that plan } \\
\text { clearly to employees, and demonstrate that the plan is being implemented effectively. Trust } \\
\text { is a two-way street. Leaders must also show that they, in tum, trust employees to help drive } \\
\text { organizational success. They must make employees valued partners in a common } \\
\text { enterprise. Employees want not only to know what the bigger picture is, but also to feel that } \\
\text { they are a part of that picture. }\end{array}$ & $\begin{array}{l}\text { Hughes \& Rog (2008), Gallup } \\
\text { (2011), Covey (2009), Mone et al. } \\
\text { (2011), Schroeder-Saulnier (2010) }\end{array}$ \\
\hline 7 & Nature of my job & $\begin{array}{l}\text { This driver, 'nature of my job', is defined as the extent of employee participation and } \\
\text { autonomy. Encouraging employee accountability is a key aspect. Advocating the thought of } \\
\text { accountability ensures that people are trusted with a job, the responsibility that comes with } \\
\text { the job and are expected to complete the job in stipulated time intervals. The way to drive } \\
\text { engagement to the highest levels is by empowering employees and by making sure that all } \\
\text { employees are held accountable for achieving results. Moreover, these areas are important } \\
\text { to attract, retain, and motivate the most talented employees. People who value } \\
\text { empowerment and accountability will be discouraged in companies that do not promote and } \\
\text { support these things. In contrast, poor performers might enjoy the safe haven if a company } \\
\text { does not demand accountability. These are employees who might have high levels of } \\
\text { 'satisfaction', but they are likely to be adding little or no value, and even worse, discouraging } \\
\text { the talented people around them. }\end{array}$ & $\begin{array}{l}\text { Hughes \& Rog (2008), Kanaka } \\
\text { (2012), Gallup (2011), } \\
\text { Custominsight (2013) }\end{array}$ \\
\hline 8 & $\begin{array}{l}\text { The connection between } \\
\text { individual and company } \\
\text { performance }\end{array}$ & $\begin{array}{l}\text { 'Connection between individual and company performance' refers to the extent to which } \\
\text { employees understand the company's objectives, current levels of performance, and how } \\
\text { best to contribute to them. Goal setting is a critical component of performance management } \\
\text { and when managers and employees set goals collaboratively, employees become more } \\
\text { engaged. Top management needs to allow free flow of information, such as industry } \\
\text { updates, sectoral updates, quality issues, compliances, and employee development updates } \\
\text { to ensure that employee engagement is a driver of success. Many great workplaces have } \\
\text { defined the right outcomes; they set goals for their work groups or work with them to set their } \\
\text { own goals. They do not just define the job, but define success on the job. An effective } \\
\text { workplace provides constant clarification of the overall mission of the organization, as well as } \\
\text { the ways in which each individual team member contributes to the achievement of the } \\
\text { mission. Individual achievement is great, but employees are likely to stay committed for } \\
\text { longer if they feel that they are part of 'something bigger than themselves. }\end{array}$ & $\begin{array}{l}\text { Hughes \& Rog (2008), Kanaka } \\
\text { (2012), Mone et al. (2009), Gallup } \\
\text { (2011) }\end{array}$ \\
\hline 9 & $\begin{array}{l}\text { Career growth } \\
\text { opportunities }\end{array}$ & $\begin{array}{l}\text { Career growth opportunities refer to the extent to which employees have opportunities } \\
\text { for career growth and promotion or have a clearly defined career path. Employee } \\
\text { engagement is also directly predicted by the extent to which employees are satisfied } \\
\text { with their opportunities for career progression and promotion, suggesting that } \\
\text { employees will feel more engaged if managers provide challenging and meaningful } \\
\text { work with opportunities for career advancement. When managers provide sufficient } \\
\text { opportunities for training and support regarding career development efforts, they help } \\
\text { foster employee development and drive employee engagement. 'Great' workplaces } \\
\text { are those in which work groups are provided with educational opportunities that } \\
\text { address their development, which may include formal classes or simply finding new } \\
\text { experiences for them to take on. This research also defines opportunities as training } \\
\text { classes and seminars for some and for others this might mean promotions and } \\
\text { increased responsibilities, while for others this might mean working on special projects } \\
\text { and assignments. }\end{array}$ & $\begin{array}{l}\text { Hughes \& Rog (2008), Mone et al. } \\
\text { (2009), Kanaka (2012), Gallup } \\
\text { (2012) }\end{array}$ \\
\hline 10 & Stress-free environment & $\begin{array}{l}\text { A stress-free environment means that employees put in their best efforts so they can } \\
\text { innovate and be creative ensuring optimum output. Most people have found out that } \\
\text { when they work in a fun and relaxing atmosphere, they can be more relaxed, which } \\
\text { means they can be more successful. They can share their personal ideas and } \\
\text { experiences, and in a healthy working environment, it should be encouraged. All } \\
\text { employees should feel valued and appreciated. You can start fun team-building } \\
\text { experiences to get things started. Commitment and involvement are also very } \\
\text { important factors that contribute to the success factors of businesses and engagement } \\
\text { within the workplace. Many research studies have proved that people will stay with a } \\
\text { company longer if they feel involved and needed. No one wants to work in a stressful } \\
\text { and rude environment. Everyone's opinions should be listened to and considered. This } \\
\text { will lead to a decreased rate of employee turnover, which is definitely a goal for any } \\
\text { business. }\end{array}$ & $\begin{array}{l}\text { Kanaka (2012), Aveta Business } \\
\text { Institute (2014) }\end{array}$ \\
\hline
\end{tabular}


Table 1 (cont.). Employee engagement constructs

\begin{tabular}{|c|c|c|c|}
\hline № & Construct & Description & Researchers \\
\hline 11 & Change management & $\begin{array}{l}\text { Employee engagement and change management are described as "The greater an } \\
\text { employee's engagement, the more likely he or she is to 'go the extra mile' and deliver } \\
\text { excellent on-the-job performance." (Dicke et al., 2007:50). Therefore, if employees are } \\
\text { engaged during a change management initiative they are likely to have increased 'buy- } \\
\text { in' and better performance, thereby supporting business success. Employee } \\
\text { engagement is a primary function towards the success of properly implementing a } \\
\text { change management initiative, and due to employee engagement's close relationship } \\
\text { to organizational commitment, understanding organizational commitment's relationship } \\
\text { to change management may provide some valuable insight. Employees who are } \\
\text { engaged in their work and committed to their organizations provide crucial competitive } \\
\text { advantages, such as higher productivity and lower employee turnover. If employees } \\
\text { are engaged during a change management initiative, they are likely to have increased } \\
\text { 'buy-in' and better performance, thereby supporting business success." }\end{array}$ & $\begin{array}{l}\text { Kanaka (2012), (Dicke, Holwerda } \\
\text { \& Kontakos, 2007), Vance (2006) }\end{array}$ \\
\hline
\end{tabular}

Source: compiled from Imandin (2015a, 2015b).

Table 5. Standardized regression weights

\begin{tabular}{|c|c|c|c|}
\hline & & & Estimate \\
\hline EPMandL & $<--$ & EmpEng & .811 \\
\hline FVandl & $<--$ & EmpEng & .848 \\
\hline $\mathrm{BE}$ & $<--$ & EmpEng & .628 \\
\hline EE & $<--$ & EmpEng & .818 \\
\hline CGO & $<--$ & EmpEng & .770 \\
\hline NOMJ & $<--$ & EmpEng & .667 \\
\hline CMandSE & $<--$ & EmpEng & .852 \\
\hline ELT & $<--$ & EPMandL & .952 \\
\hline EPM & $<--$ & EPMandL & .949 \\
\hline emp1 & $<--$ & $\mathrm{BE}$ & .763 \\
\hline emp5 & $<--$ & $\mathrm{BE}$ & .776 \\
\hline emp6 & $<--$ & $\mathrm{BE}$ & .792 \\
\hline emp11 & $<--$ & BE & .817 \\
\hline emp16 & $<--$ & $\mathrm{BE}$ & .740 \\
\hline emp19 & $<--$ & $\mathrm{BE}$ & .791 \\
\hline emp20 & $<--$ & $\mathrm{BE}$ & .839 \\
\hline emp23 & $<--$ & $\mathrm{BE}$ & .702 \\
\hline emp24 & $<--$ & $\mathrm{BE}$ & .711 \\
\hline emp25 & $<--$ & $\mathrm{BE}$ & .859 \\
\hline emp26 & $<--$ & $\mathrm{BE}$ & .755 \\
\hline emp27 & $<--$ & $\mathrm{BE}$ & .726 \\
\hline emp82 & $<--$ & CMandSE & .758 \\
\hline emp83 & $<--$ & CMandSE & .805 \\
\hline emp84 & $<--$ & CMandSE & .798 \\
\hline emp85 & $<--$ & CMandSE & .885 \\
\hline emp86 & $<--$ & CMandSE & .893 \\
\hline emp87 & $<--$ & CMandSE & .865 \\
\hline emp88 & $<--$ & CMandSE & .864 \\
\hline emp89 & $<--$ & CMandSE & .803 \\
\hline emp90 & $<--$ & CMandSE & .848 \\
\hline emp91 & $<--$ & CMandSE & .800 \\
\hline emp92 & $<--$ & CMandSE & .705 \\
\hline emp93 & $<--$ & CMandSE & .711 \\
\hline emp73 & $<--$ & CGO & .850 \\
\hline emp74 & $<--$ & CGO & .870 \\
\hline emp75 & $<--$ & CGO & .783 \\
\hline emp76 & $<--$ & CGO & .823 \\
\hline emp77 & $<--$ & CGO & .761 \\
\hline emp78 & $<--$ & CGO & .818 \\
\hline emp79 & $<--$ & CGO & .822 \\
\hline emp80 & $<--$ & CGO & .802 \\
\hline emp81 & $<--$ & CGO & .849 \\
\hline
\end{tabular}


Problems and Perspectives in Management, Volume 14, Issue 2, 2016

\begin{tabular}{|c|c|c|c|}
\hline & & & Estimate \\
\hline emp7 & $<--$ & $\mathrm{EE}$ & .823 \\
\hline emp8 & $<--$ & $\mathrm{EE}$ & .871 \\
\hline emp9 & $<--$ & $\mathrm{EE}$ & .916 \\
\hline emp12 & $<--$ & $\mathrm{EE}$ & .897 \\
\hline emp13 & $<-$ & $\mathrm{EE}$ & .789 \\
\hline emp17 & $<--$ & $\mathrm{EE}$ & .854 \\
\hline emp18 & $<-$ & $\mathrm{EE}$ & . 772 \\
\hline emp21 & $<--$ & $\mathrm{EE}$ & .851 \\
\hline emp60 & $<--$ & NOMJ & . 762 \\
\hline emp61 & $<--$ & NOMJ & .864 \\
\hline emp62 & $<--$ & NOMJ & .832 \\
\hline emp94 & $<--$ & NOMJ & .639 \\
\hline emp3 & $<--$ & FVandl & . 445 \\
\hline emp4 & $<--$ & FVandl & .673 \\
\hline emp30 & $<--$ & FVandl & .713 \\
\hline emp36 & $<-$ & ELT & .739 \\
\hline emp37 & $<-$ & ELT & .839 \\
\hline emp38 & $<--$ & ELT & .840 \\
\hline emp39 & $<--$ & ELT & .862 \\
\hline emp40 & $<--$ & ELT & .835 \\
\hline emp41 & $<-$ & ELT & .834 \\
\hline emp42 & $<--$ & ELT & .843 \\
\hline emp43 & $<--$ & ELT & .860 \\
\hline emp44 & $<--$ & ELT & .862 \\
\hline emp45 & $<-$ & ELT & .849 \\
\hline emp46 & $<--$ & EPM & .833 \\
\hline emp47 & $<--$ & EPM & .703 \\
\hline emp48 & $<--$ & EPM & .844 \\
\hline emp49 & $<--$ & EPM & .875 \\
\hline emp50 & $<--$ & EPM & .871 \\
\hline emp51 & $<--$ & EPM & . 916 \\
\hline emp52 & $<--$ & EPM & .898 \\
\hline emp53 & $<--$ & EPM & . 844 \\
\hline emp54 & $<--$ & EPM & .887 \\
\hline emp55 & $<--$ & EPM & .864 \\
\hline
\end{tabular}

